\title{
牛肉の購買行動における消費者意識構造の把握
}

一共分散構造分析を用いた解析一

\author{
長命 洋佑 ${ }^{1) *}$ ・広岡 博之 ${ }^{2)}$
}

\section{Structure of Consciousness in Purchasing Behavior of Beef: A Structural Equation Modeling Analysis}

\author{
Yosuke Chomei ${ }^{1) *} \&$ Hiroyuki Hirooka ${ }^{2)}$
}

The objective of this study was to investigate the relationship between consumers' purchasing consciousness and the purchasing price of beef, using the results of an internet questionnaire survey focused on female consumers. The following three factors were obtained from the analysis: (1) intrinsic quality value, which is associated with the physical and physiological characteristics of the beef itself, (2) extrinsic quality value, which is associated with socioキーワード : 牛肉, アンケート調査, 因子分析, 女性消費者

\section{1.はじめに}

わが国の食肉の供給量は, 1960 年には 1 人 1 年当 たりわずか $3.5 \mathrm{~kg}$ であったが， 2013 年はその 10 倍 の $30 \mathrm{~kg}$ となった. 1991 年の輸入牛肉の自由化を契 機に輸入牛肉の消費が増加したが, 2001 年にわが国 で, 2003 年に米国でBSE (牛海綿状脳症) が発生 し, わが国の牛肉消費量は大きく減退し, 今も BSE 発生前の水準には回復していない.

その一方で，わが国の枝肉市場に打ける枝肉価格 は, これまで主に脂肪交雑の程度によって決定され， その価格がそのまま消費者が購入する牛肉価格に反 映されてきた。しかし, 近年では, 海外からの安価 な牛肉だけでなく、テレビのグルメ番組などを通じ て，様々な情報が容易に手に入るようになり，消費 economic factors such as information about the famer, brand, and origin, and (3) the display value of the date such as expiration date and packing date. The results of the structural equation modeling (SEM) analysis showed that the purchasing price of beef is influenced by two factors: the "extrinsic quality value" and the "display value of date." The former had a positive effect, while the latter had a negative effect, on the purchasing price of beef.

者にとって牛肉はより身近な食べ物となった．今後， 消費者の牛肉へのニーズは，高度化かつ多様化して いくとともに, 購買行動に执いても重視する点が変 化していくことが考えられる.

これまでの先行研究をみてみると, 国外では消費 者の食肉購買に関与寸る要因として，消費者の個人 的な属性に関する要因, 対象の食肉が持つ官能や栄 養学的特質, ラベルや生産情報なぞ外的な要因が取 り上げられ (Font-i-Furnols and Guerrero, 2014)， Bredahl（2003）や Reicks et al.（2011）は牛肉に関 してこれらの要因の効果の大きさを定量化する研究 を行っている。また，わが国では，金他（2001） は，因子分析を用いて，女性消費者に打沙る牛肉購 買パターンを分析し，ブランドの役割は高級品であ

1) 九州大学大学院農学研究院; Faculty of Agriculture, Kyushu University

2) 京都大学大学院農学研究科; Graduate School of Agriculture, Kyoto University

*E-mail: chomei@agr.kyushu-u.ac.jp 
るといら 1 次元的な尺度から不確実性の低減など多 元的な尺度へと展開していることを指摘している。 新山他（2007）は，発話思考プロトコル分析を用い て, 店頭での消費者の購買行動を分析した結果, 牛 肉は野菜や卵，牛乳に比べ提供されている情報数が 多く，また探索された情報数も多いことを指摘して いる. Sasaki and Mitsumoto（2004）や佐々木他 （2006）は，一般公開のイベントに訪れた来訪者を 対象に, 牛肉消費に関するアンケート調査を実施し, 肉質に対するニーズや購買時の着目点について検討 している.しかし，これらの先行研究に拈いては， 消費者の購買意識や行動が購買価格に及ぼす影響は 明らかにされていない，そこで本稿では，女性消費 者を対象とした牛肉の購買と消費に関するアンケー 卜調査の結果を用いて, 牛肉の購買行動に拈ける意 識構造の把握を行ったらえで, 実際の購入価格との 関係を明らかにすることを課題とする.

\section{2. 用いたデータと分析方法}

本稿に打ける調査は，インターネットアンケート 会社のマクロミルに依頼し, 月に 2,3 回以上牛肉を 購入している全国の女性消費者を対象に，2014 年 12 月 17 日から 2014 年 12 月 22 日にかけてインター ネットアンケートを実施した。 調査対象は, 表 1 に 示す地域に居住している 25 歳以上 64 歳以下の女性
消費者（各地域で同人数を抽出）1,040 名を対象に 調査を行った。本稿では，世帯年収に関する欠損值 を除いた 839 名のデータを分析に用いた。

アンケートの調査項目に拈いては，年齢や職業な どの基本属性のほかに，新山他（2007）で明らかに されている店頭に打ける表示情報を参考に「牛肉を 購入する際に重視する項目」として 15 項目を質問 し，それぞれの項目に対して「非常に重視している」 から「全く重視していない」までの 7 段階評価を設 定した。また，牛肉の購入価格に関しては，消費者 が普段購入している $100 \mathrm{~g}$ 当たりの牛肉の価格帯に ついて質問を行った。価格帯の設定に関しては, $100 \mathrm{~g}$ 当たり 98 円から 998 円までの価格帯は50 円 刻みで，それ以上の価格帯では100 円刻みで最大 2,000 円以上までの選択肢を設定した.

本稿では,「牛肉を購入する際に重視する項目」に 関して，新山他（2007）で指摘された消費者によっ て探索された情報（外観・賞味期限・国拈よび産地・ 部位・カット形態・脂肪・価格など）に関する消費 者の意識構造を明らかにすることを目的に探索的因 子分析を行い意識構造の把握を行った．次いで，普 段購入している牛肉の購入価格を被説明変数として 取り上げ，「牛肉を購入する際に重視する項目」より 抽出した因子を説明変数とした共分散構造分析を行 い, 牛肉の購入価格を規定している要因の解明を行

表 1. 調査対象者の内訳と普段購入する牛肉の価格 単位 : \%, 円/100 g

\begin{tabular}{|c|c|c|c|c|c|c|c|c|}
\hline 年齢 & & & 居住地域 & & & 普段購入する牛肉 & & \\
\hline$\sim 29$ 歳 & 9.2 & 282.4 & 北海道 & 9.8 & 354.2 & 輸入牛肉 ${ }^{1)}$ & 41.5 & 249.9 \\
\hline $30 \sim 39$ 歳 & 25.4 & 318.2 & 東北 & 10.3 & 307.3 & 国産牛肉 & 58.5 & 445.4 \\
\hline $40 \sim 49$ 歳 & 27.8 & 330.6 & 関東 & 19.4 & 385.1 & 世帯年収 & & \\
\hline $50 \sim 59$ 歳 & 27.1 & 413.3 & 東海・北陸 & 19.5 & 357.2 & 200 万円未満 & 6.3 & 332.0 \\
\hline 60 歳以上 & 10.6 & 508.7 & 近畿 & 21.2 & 400.9 & 200～399 万円 & 25.6 & 347.1 \\
\hline 職業 & & & 中国・四国 & 8.9 & 339.3 & 400～599 万円 & 29.4 & 332.9 \\
\hline 公務員 & 2.0 & 392.1 & 九州・沖縄 & 11.0 & 351.9 & 600～799 万円 & 18.0 & 387.4 \\
\hline 会社員 & 19.4 & 387.9 & 結婚の有無 & & & $800 \sim 999$ 万円 & 9.9 & 398.0 \\
\hline 自営業など & 5.0 & 487.4 & 未婚 & 24.8 & 383.6 & 1,000 万円以上 & 10.7 & 440.8 \\
\hline 専業主婦 & 42.8 & 368.7 & 既婚 & 75.2 & 357.9 & & & \\
\hline パート・ & 25.0 & 308.3 & 子供の有無 & & & & & \\
\hline アルバイト & & & 子供なし & 33.5 & 371.2 & & & \\
\hline その他・無職 & 5.7 & 372.0 & 子供あり & 66.5 & 360.9 & & & \\
\hline
\end{tabular}

資料：アンケート調査より筆者作成.

1）輸入牛肉を購入する内訳は，アメリカ産が $21.3 \%$ ，オーストラリア産が $78.7 \%$ オっている. 
った，最後に，年齢，職業，収入なぞの基本属性に 関する変数をそれぞれグループに分けて，多母集団 の同時解析を行い，各対象グループに同じモデルが ぞの程度まで仮定できるかの評価を行った。なお， 分析には, SPSS22.0 およびAmos22.0を用いた。

\section{3. 分析結果および考察}

\section{（1）回答者の基本属性と普段購入する牛肉の価格}

本稿で用いた調查対象者の内訳は，表 1 亿示寸通 りである. 調査対象の年齢は, $30 \sim 59$ 歳までの各層 の割合は $25 \sim 27 \%$ 前後であり，その他の階層は $10 \%$ 前後であった．牛肉の購入価格は，年齢層が高くな るにつれて購入価格も高くなる傾向が見られた，職 業に関しては，専業主婦が多く $(42.8 \%)$, 次いで, パート・アルバイト $(25.0 \%)$, 会社員 $(19.4 \%)$ の 順となっていた．牛肉の購入価格は，自営業などで 最も高く, 次いで公務員, 会社員の順で高かった。

居住地域に関しては, 近畿地方が最も多く $(21.2 \%)$, 次いで，東海・北陸地方 $(19.5 \%)$, 関東 地方 (19.4\%) の順で多かった. このことから，現 在の人口分布と比べると北海道・東北の回答者が多 く, 関東の回答者が相対的に少ないことは留意すべ きと考兄られる. 牛肉の購入価格は, 近畿地方が 400.9 円 $/ 100 \mathrm{~g}$ と最も高く, 次いで関東地方で高かっ た $(385.1$ 円 $/ 100 \mathrm{~g})$. 一方, 最も低かったのは東北 地方 $(307.3$ 円 $/ 100 \mathrm{~g})$ であった. 結婚の有無に関し ては, $75.2 \%$ が既婚であり, 牛肉の購入価格は未婚 層で購入価格が高かった（383.6 円/100 g)。供の 有無では，66.5\%で子供がいるとの回答となって拉 り，購入価格に関しては，子供のいない層に打いて 高かった $(371.2$ 円 $/ \mathrm{kg})$.

普段購入する牛肉に扔いては, 国産牛肉を購入し ている消費者は $58.5 \%$, 輸入牛肉を購入している消 費者は $41.5 \%$ であった。 そのうち，アメリカ産が $21.3 \%$ ，オーストラリア産が $78.3 \%$ となって打り， 今日でも多くの消費者が，アメリカ産牛肉の安全性 に対して不信感を抱いていることが示唆される結果 であった，購入価格に関しては，輸入牛肉が 249.9 円/100 g，国産牛肉が 445.4 円/100 g となっていた.

世帯年収に関しては，400 600 万円未満が最も多 く(29.4\%), 次いで 200 400 万円未満の回答が多 かった. 牛肉の購入価格に関しては, 200〜399 万円
の層で高くなっているが，世帯収入が高くなるにつ れて，購入価格が高くなる傾向が見られた。

\section{（2）回答者の牛肉購買意識}

表 2 は, 調査対象者に打ける「牛肉を購入する際 に重視する項目」の平均点打よび標準偏差を示した ものである.最も重視していたのは「価格」であり， 次いで「消費期限」,「肉の色つやなどの「見た目」」, 「国産・海外産などの「産地名」」,「「バラ」や「肩口 一ス」なぞの「部位」」，「加工年月日」が高い値を示 して招り，標準偏差も相対的に高かった。これらの 項目は，新山他（2007）が指摘していたのと同様 に，購入に際して重視している項目であるといえる.

以上の結果より，普段消費者が購入する牛肉は， 店頭に执いて比較的短期間で判断できる情報，例え ば商品ラベルに記された情報などが購買行動に寄与 していることが示唆された. その一方で, 金他 (2001) が指摘していたブランド牛に対する評価や「企業名・ 農場名なぞの「生産者」の情報」，「牛の「個体識別 番号」」は低い值となっていた。特に個体識別番号

表 2. 牛肉を購入する際に重視する項目

\begin{tabular}{|c|c|c|}
\hline & 平均値 1) & 標準偏差 \\
\hline 価格 & 5.42 & 1.62 \\
\hline 消費期限 & 5.09 & 1.69 \\
\hline 肉の色やつやなどの「見た目」 & 4.73 & 1.66 \\
\hline 国産・海外産などの「産地名」 & 4.66 & 1.72 \\
\hline $\begin{array}{l}\text { 「バラ」や「肩ロース」などの } \\
\text { 「部位」 }\end{array}$ & 4.64 & 1.60 \\
\hline 加工年月日 & 4.63 & 1.67 \\
\hline $\begin{array}{l}\text { 「焼肉用」や「ステーキ用」などの } \\
\text { 「用途」 }\end{array}$ & 4.37 & 1.56 \\
\hline 赤身部分の多さ & 4.28 & 1.50 \\
\hline 肉の周りの脂肪の薄さ & 4.18 & 1.48 \\
\hline 霜降りの度合い & 4.09 & 1.46 \\
\hline $\begin{array}{l}\text { 販売店（または販売組織）の } \\
\text { 「信頼度」 }\end{array}$ & 4.08 & 1.62 \\
\hline $\begin{array}{l}\text { 「松坂牛」や「神戸牛」などの } \\
\text { 産地・銘柄の「ブランド」 }\end{array}$ & 3.89 & 1.41 \\
\hline 牛肉の熟成の度合い & 3.61 & 1.06 \\
\hline $\begin{array}{l}\text { 企業名・農場名などの } \\
\text { 「生産者」の情報 }\end{array}$ & 3.57 & 1.26 \\
\hline 牛の「個体識別番号」 & 3.07 & 1.18 \\
\hline
\end{tabular}

資料：アンケート調査より筆者作成.

1）「非常に重視している」の 7 点から「全く重視していな い」の 1 点までを割り当てた. 
表 3. 牛肉を購入する際に重視する項目に関する因子分析の結果

\begin{tabular}{|c|c|c|c|c|}
\hline & & 内因性価値 & 外因性価値 & 日付表示 \\
\hline 赤身部分の多さ & 【赤身部分】 & 0.885 & -0.117 & -0.097 \\
\hline 肉の周りの脂肪の薄さ & 【脂肪の薄さ】 & 0.776 & -0.055 & -0.046 \\
\hline 霜降りの度合い & 【霜降り】 & 0.622 & 0.118 & -0.018 \\
\hline 肉の色やつやなどの「見た目」 & 【見た目】 & 0.552 & -0.018 & 0.137 \\
\hline 「バラ」や「肩ロース」などの「部位」 & 【部位】 & 0.530 & 0.030 & 0.134 \\
\hline 企業名・農場名などの「生産者」の情報 & 【生産者情報】 & -0.058 & 0.750 & -0.082 \\
\hline 「松坂牛」や「神戸牛」などの産地・銘柄の「ブランド」 & 【ブランド牛】 & 0.064 & 0.688 & -0.038 \\
\hline 牛の「個体識別番号」 & 【個体識別番号】 & -0.170 & 0.594 & -0.007 \\
\hline 販売店（または販売組織）の「信頼度」 & 【店の信頼度】 & 0.081 & 0.590 & 0.062 \\
\hline 国産・海外産などの「産地名」 & 【産地名】 & 0.175 & 0.487 & 0.129 \\
\hline 消費期限 & 【消費期限】 & -0.036 & -0.079 & 1.029 \\
\hline \multirow[t]{3}{*}{ 加工年月日 } & 【加工年月日】 & 0.044 & 0.065 & 0.698 \\
\hline & $\alpha$ 係数 & 0.811 & 0.766 & 0.841 \\
\hline & 累積因子負荷量（\%） & 24.7 & 41.4 & 50.6 \\
\hline
\end{tabular}

資料：アンケート調査より筆者作成.

は，消費者が牛肉の購買の意思決定に利用しておら ず，一般消費者への浸透度が低いことが示された。

\section{（3）因子分析の結果}

以下では,「牛肉を購入する際に重視する項目」に 関連する消費者の意識構造を明らかにする. 表 3 は, 最尤法・プロマックス回転による最終的な因子分析 の結果を示したものである．分析にあたっては，固 有值 1 以上の条件で因子を抽出した。 またその際, 因子負荷量が 0.4 に満たない項目を削除し, 再度分 析を繰り返した。な抽，この過程に拈いて「価格」 は削除されたが，このことは他の項目に対し，包括 的に影響を及ぼしていたためと考兄られる。

分析の結果，3つの因子が抽出された。第 1 因子 に寄与していたのは，「赤身部分」「脂肪の薄さ」「霜 降り」「見た目」「部位」の 5 変数であった。 これら は, 牛肉そのものが持つ価值であるため「内因性価 値」と呼ぶこととした，第 2 因子は，「生産者情報」 「ブランド牛」「個体識別番号」「店の信頼度」「産地 名」の 5 変数で構成されていた. これらは, 外部か らの情報によって決まる価值に関する変数で構成さ れていたため「外因性価值」と呼ぶこととした，第 3 因子は,「消費期限」および「加工年月日」が寄与 していたため「日付表示」と呼ぶこととした。

\section{（4）共分散構造分析の結果}

以下では, 抽出された $3 つ の$ 因子が牛肉の購入価
格に及ぼす影響を明らかにするために，共分散構造 分析を用いて，その因果関係モデルの構築を試みた。

本稿では，3つの因子すべてが「購入価格」に影 響を及ぼすことを仮定し分析を行った。結果は，図 1 亿示すと扬りである。モデルの当てはまりは， GFI=0.919, AGFI=0.879, RMSEA=0.085 であった. 牛肉の購入価格に影響を及ぼしているのは,「外因性 価値」扣よび「日付表示」の 2 因子であり,「外因性 価値」のパス係数は正の值（0.35）を，「日付表示」 は負の值（-0.12）を示していた，以上の結果より， 牛肉の購入価格に関しては, 牛肉そのものから得ら れる情報よりも外部からの情報，例光ば商品のラ心 ルなどの情報をより重視していることが示唆された。 消費者は，商品ラベルに記入されているブランド牛 や産地名などの情報を基に，購入するかどらかを判 断しているといえる。また，「日付表示」を重視して いる消費者は低価格の牛肉を購入する傾向が見られ た.この結果は，スーパーなどでは牛肉の消費期限 が迫って来た場合, 值下げ商品となる場合が多く, そのため，消費者は值下げ時期を見計らって，通常 価格よりも安価で牛肉を購入していることが結果に 反映したと考えられた。

さらに本稿では, 個人属性に関連する変数をグル ープに分けて，多母集団の同時解析を行い，グルー プ間のパス係数の比較を行った．分析に用いたグル 


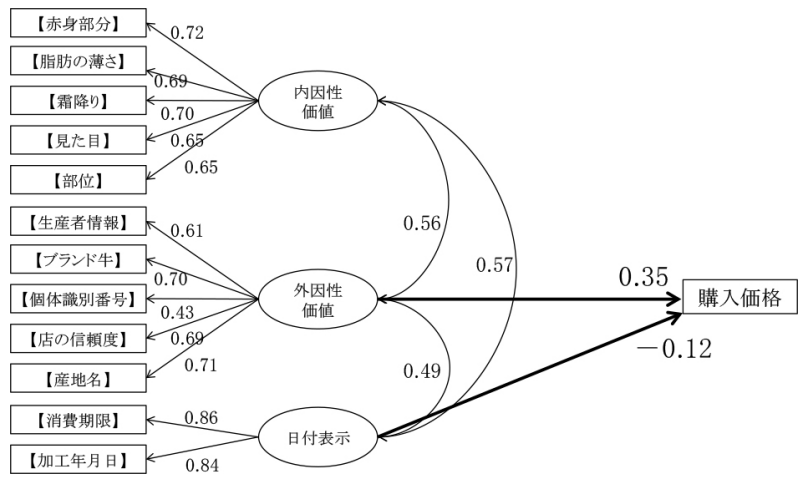

図 1. 消費者の購買意識が購入価格に与える影響 1)

資料：アンケート調査より筆者作成.

1）誤差項は省いて作図した.

表 4. パス係数の推定值とグループ間の多母集団同時解析

\begin{tabular}{|c|c|c|c|}
\hline & & 外因性価値 ${ }^{1)}$ & 日付表示 1) \\
\hline \multirow[t]{3}{*}{ 年齢 } & 50 歳未満 & $0.300 * * *$ & $-0.119 * *$ \\
\hline & 50 歳以上 & $0.318 * * *$ & $-0.247 * *$ \\
\hline & 有意差の検定 & 0.225 & -1.446 \\
\hline \multirow[t]{3}{*}{ 職業 } & 主婦 & $0.318 * * *$ & -0.121 \\
\hline & 主婦以外 & $0.330 * * *$ & $-0.148 * *$ \\
\hline & 有意差の検定 & -0.132 & -0.329 \\
\hline \multirow[t]{3}{*}{ 結婚の有無 } & 未婚 & $0.393 * * *$ & -0.182 \\
\hline & 既婚 & $0.310 * * *$ & $-0.125 * *$ \\
\hline & 有意差の検定 & 0.680 & -0.427 \\
\hline \multirow[t]{3}{*}{ 子供の有無 } & 子供なし & $0.395 * * *$ & -0.050 \\
\hline & 子供あり & $0.305 * * *$ & $-0.180 * *$ \\
\hline & 有意差の検定 & -1.036 & -1.135 \\
\hline \multirow[t]{3}{*}{ 普段購入する牛肉 } & 輸入牛肉 & 0.040 & -0.028 \\
\hline & 国産牛肉 & $0.355 * * *$ & $-0.174 * * *$ \\
\hline & 有意差の検定 & $3.707 * * *$ & $-1.874 * * *$ \\
\hline \multirow[t]{3}{*}{ 世帯年収 } & 600 万円未満 & $0.281 * * *$ & $-0.181 * * *$ \\
\hline & 600 万円以上 & $0.408 * * *$ & -0.064 \\
\hline & 有意差の検定 & 1.238 & 1.021 \\
\hline
\end{tabular}

資料：アンケート調査より筆者作成.

1）有意差検定の絶対值が「1.96」以上であればパス係数の差が $5 \%$ 水準（**）で有意，絶対值で「2.33」 以上であれば $1 \%$ 水準 $(* * *)$ で有意である.

ープの因果関係は, 図 1 と同様であり, その結果を 示したのが表 4 である.「普段購入する牛肉」に関し て 2 つグループを比較したところ,「外因性価值」 および「日付表示」の 2 因子とも「購入価格」に対 するパス係数に有意な差が見られた。普段購入する
牛肉として国産牛肉を購入している場合,「外因性価 値」を重視している消費者毛，牛肉の「購入価格」 が高くなる傾向がある一方で，「日付表示」を重視し ている消費者ほど，「購入価格」が低くなる傾向にあ ることが明らかとなった。 また，「日付表示」に拈い 
て，専業主婦以外の層，子供のいる消費者，600 万 円未満の消費者で有意差がみられた。ただし，これ らの変数に扣いて，グループ間の差を検定したとこ ろ，パス係数に有意な差は見られなかった。

牛肉は，実際に食べてみないとおいしいかどらか わからないらえに, 購入したものは一度しか消費で きないものである、工業とは異なり, 同じ産地や生 産者, ブランド牛（品種）であっても品質が一定と は限らない，そのため消費者にとって外部からの情 報が商品購入の重要な指標となっているといえる(佐 々木他 2006)。新山他（2007）では, 食品の購入時 に执いて，多くの情報を提示しても消費者は短時間 で判断できず，利用されない可能性が高いことを指 摘したらえで，表示の信頼性を高めることが重要で あると述べている。 また, 消費者は健康, 倫理, 安 全性，文化といった外面的観察だけではとらえるこ とのできない部分に関心の重点が移ってきているた め, 食品の持つ情報を正確かつ効率的に消費者に伝 えることが社会的な要請として顕在化してきている ことを茂野（2012）は指摘している。

本稿の結果は, BSE 事件や牛肉偽装表示問題なぞ の発生により, 消費者がより牛肉購入に慎重になっ たため, 外部からの情報をより重視していることが 結びついたと考兄られる. TPP 交渉が大筋合意に至 り, 今後, 海外産の牛肉がより身近な存在になるこ とも考光られるため, これまで以上に外部からの情 報の信頼性が重要となってくることが示唆される。

\section{4. おわりに}

本稿では, 女性消費者を対象とした牛肉購買行動 に関するアンケート調査より, 牛肉の購買行動にお ける意識構造の把握を行った. 分析の結果, 以下の 2 点が明らかとなった. 第一に, 牛肉購入時に重視 している点として 3 つ因子が抽出された. それら は, 牛肉そのものが持つ価值に関する「内因性価 值」, 外部からの情報によって決まる価値を示す「外 因性価值」和よび消費期限・加工日を示す「日付表 示」に関する因子であった. 第二に, 牛肉購入時に 重視する項目と牛肉の「購入価格」との関係を分析 した結果，「購入価格」に影響を及ぼしているのは, 「外因性価値」「日付表示」の 2 つの因子であった.
「外因性価値」を重視している消費者は，商品ラベル など外部からの情報を重視し，より高い牛肉を購入 していること，また「日付表示」を重視している消 費者は，消費期限が迫った割引商品を購入すること で, より安く牛肉を購入していることが示唆された。

今後は，如何なる外因性価値の情報を牛肉打よび 商品ラベルに付記していくのか，有効な情報提示に 関する検討を行っていくことが重要であるといえる. また，本稿の調査対象は，月に 2,3 回以上牛肉を購 入している女性消費者としたため，男性を対象と寸 ることや購入回数の制限をなくした分析を行らこと で，多面的な考察を行うことが可能と考光る.

\section{謝辞}

本稿は, 日本学術振興会科学研究費助成事業（基 盤研究 (C) 特設分野課題番号：26520306）打よび 伊藤記念財団研究調查助成による研究成果である. 改めて感謝の意を示す。

\section{引用文献}

金 英美・大森賢一・谷口憲治（2001）「消費者の牛肉購買パ ターンとその要因」『農林業問題研究』36(4), 245-248.

佐々木啓介・三津本充・合崎英男（2006）「牛肉購入時に打け る消費者の着眼点の分類」『日本畜産学会報』77(1), 67-76. 茂野隆一（2012）「食料消費行動分析の新展開」『フードシステ 么研究』19(2), 37-45.

新山陽子・西川 朗・三輪さち子（2007）「食品購買における 消費者の情報処理プロセスの特質一認知的概念モデルと発 話思考プロトコル分析一」『フードシステム研究』14(1), 15-33.

Bredahl, L. (2003) Cue utilization and quality perception with regard to branded beef. Food Quality and Preference, 15, 6575.

Font-i-Furnols, M. and Guerrero, L. (2014) Comsumer preference, behavior and perception about met and meat products: An overview. Meat Science, 98, 361-371.

Reicks, A. L., Brook, J. C., Garmyn, A. J., Thampson, L. D., Lyford, C. L. and Miller, M. F. (2011) Demographics and beef preferences affect consumer motivation for purphased fresh beef steaks and roasts. Meat Science, 87, 403-411.

Sasaki, K. and Mitsumoto, M. (2004) Questionnaire-based study on consumer requirements for beef quality in Japan. Animal Science Journal, 75, 369-376. 